\title{
Evaluation of potential reference genes in real-time RT-PCR studies of Atlantic salmon
}

\author{
Pål A Olsvik*1, Kai K Lie ${ }^{1}$, Ann-Elise O Jordal ${ }^{1}$, Tom O Nilsen ${ }^{2}$ and \\ Ivar Hordvik ${ }^{2}$
}

\author{
Address: ${ }^{1}$ National Institute of Nutrition and Seafood Research, Nordnesboder 2, N-5005 Bergen, Norway and ${ }^{2}$ Department of Biology, University \\ of Bergen, Thormøhlensgate 55, N-5020 Bergen, Norway \\ Email: Pål A Olsvik* - pal.olsvik@nifes.no; Kai K Lie - kai.lie@nifes.no; Ann-Elise O Jordal - ann-elise.jordal@nifes.no; \\ Tom O Nilsen - Tom.Nilsen@bio.uib.no; Ivar Hordvik - ivar.hordvik@ifm.uib.no \\ * Corresponding author
}

Published: 17 November 2005

BMC Molecular Biology 2005, 6:21 doi:10.1 |86/147|-2199-6-21

This article is available from: http://www.biomedcentral.com/147I-2199/6/21

(C) 2005 Olsvik et al; licensee BioMed Central Ltd.

This is an Open Access article distributed under the terms of the Creative Commons Attribution License (http://creativecommons.org/licenses/by/2.0), which permits unrestricted use, distribution, and reproduction in any medium, provided the original work is properly cited.
Received: 22 July 2005

Accepted: 17 November 2005

\begin{abstract}
Background: Salmonid fishes are among the most widely studied model fish species but reports on systematic evaluation of reference genes in qRT-PCR studies is lacking.

Results: The stability of six potential reference genes was examined in eight tissues of Atlantic salmon (Salmo salar), to determine the most suitable genes to be used in quantitative real-time RTPCR analyses. The relative transcription levels of genes encoding I8S rRNA, S20 ribosomal protein, $\beta$-actin, glyceraldehyde-3P-dehydrogenase (GAPDH), and two paralog genes encoding elongation factor IA (EFIA $A_{A}$ and $\left.E F I A_{B}\right)$ were quantified in gills, liver, head kidney, spleen, thymus, brain, muscle, and posterior intestine in six untreated adult fish, in addition to a group of individuals that went through smoltification. Based on calculations performed with the geNorm VBA applet, which determines the most stable genes from a set of tested genes in a given cDNA sample, the ranking of the examined genes in adult Atlantic salmon was EFIA $A_{B}>E F I A_{A}>\beta$-actin $>18 S$ rRNA $>$ S20>GAPDH. When the same calculations were done on a total of 24 individuals from four stages in the smoltification process (presmolt, smolt, smoltified seawater and desmoltified freshwater), the gene ranking was $E F I A_{B}>E F I A_{A}>S 20>\beta$-actin $>18 S$ rRNA $>G A P D H$.
\end{abstract}

Conclusion: Overall, this work suggests that the $E F I A_{A}$ and $E F I A_{B}$ genes can be useful as reference genes in $\mathrm{QRT}$-PCR examination of gene expression in the Atlantic salmon.

\section{Background}

In real-time RT-PCR, the expression levels of the target genes of interest are estimated on the basis of endogenous controls. Various housekeeping genes, ribosomal RNA (rRNA) and total RNA are most commonly used as references in gene expression analysis today. The purpose of these controls is to remove or reduce differences due to sampling, i.e. differences in RNA quantity and quality.
The ideal endogenous control should be expressed at a constant level among different tissues of an organism, at all stages of development and should be unaffected by the experimental treatment. It should also be expressed at roughly the same level as the RNA under study [1]. However, data normalization in real-time RT-PCR remains a real problem, especially for absolute quantification [1]. Numerous studies have revealed that no single universal 
gene has a constant expression level under all developmental or experimental situations. The best choice of reference gene to use as an endogenous control varies, depending on the tissues of interest in the experiment. A large number of genes have for this reason been selected for normalization of mRNA expression data [2,3]. If the selected reference gene fluctuates randomly between samples, small differences in expression between the genes of interest will be missed. Gene expression coefficient of variation $(\mathrm{CV})$ between different groups of individuals should ideally be as low as possible [4]. In general, the stability of several potential reference genes should be tested in every examined tissue or cell, and under different experimental design $[5,6]$. An increasing number of papers are discussing the selection of reference genes in real-time RTPCR analyses [3,7].

Two of the most commonly used reference genes are those encoding glyceraldehyde-3P-dehydrogenase (GAPDH) and $\beta$-actin. Recently, the use of these two genes as endogenous controls has been scrutinized, and several studies have documented that the GAPDH and $\beta$-actin genes should be used with caution as controls $[2,8,9]$. GAPDH in mammals is known to play a role in a broad range of cellular mechanisms (for review see Sirover [10]), including being a key enzyme in glycolysis. Overall, GAPDH mRNA levels might be regulated under a large number of physiological states, and its use as a reference is inappropriate for most experimental conditions. Actin is a major component of the protein scaffold that supports the cell and determines its shape, and is the most abundant intracellular protein in eukaryotic cells. Even though commonly used as a reference, the application of the $\beta$-actin gene has recently been characterized as a historical carryover from northern blots and conventional RT-PCR (for a general discussion on the use of 'classic' reference genes like GAPDH and $\beta$-actin, see Huggett et al. [7]). Eukaryotic elongation factor $1 \mathrm{~A}$ ( $\mathrm{eEF} 1 \mathrm{~A}$, formerly elongation factor 1 alpha) plays an important role in translation by catalyzing GTP-dependent binding of aminoacyl-tRNA to the acceptor site of the ribosome. However, the protein is involved in a broad diversity of functions and constitutes $1-3 \%$ of the total cytoplasmic protein content of the cell. In human, cDNAs of two actively transcribed isoforms have been cloned (eEF1A-1 and eEF1A-2) (for review see Thornton et al. [11]). Two paralog EF1A genes (A and B) have recently been applied as references in real-time qRTPCR of Atlantic salmon [12]. It is plausible to assume that the presence of these highly similar genes is a result of a tetraploidization event that occurred in a salmonid ancestor in the comparatively recent past $[13,14]$.

Previously, the $18 \mathrm{~S}$ rRNA gene was considered to be an ideal internal control in qRT-PCR analysis (Ambion [15]). Ribosomal RNA constitutes up to $80-90 \%$ of total cellular
RNA, and several studies have shown that rRNA varies less under conditions that affect the expression of mRNAs (discussed in Bustin \& Nolan [16]). However, questions have been raised against the use of ribosomal RNA genes as references. Vandesompele et al. [5] have stressed the fact that there sometimes might be imbalances in rRNA and mRNA fractions between different samples, making genes encoding ribosomal RNAs unsuitable as references. To meet these challenges of accurate interpretation of realtime qRT-PCR data, the authors suggested that an index of the most stable housekeeping genes should be used for normalization, and developed the geNorm VBA applet for Microsoft Excel in this regard [5]. A similar software tool, the BestKeeper, has been developed by Pfaffl et al. [6]. These tools can be used to find the most stable reference genes under different experimental conditions. We used the geNorm software which determines the individual stability of a gene within a pool of genes [5]. The stability is calculated according to the similarity of their expression profile by a pair-wise comparison, using their geometric mean as a normalizing factor. The gene with the highest $M$, i.e. the least stable gene, is then suggested excluded in a stepwise fashion until the most stable genes are determined, and an index suggested, based on the best genes. geNorm has been used to select the most stable reference genes in several recent studies (e.g. $[4,17,18]$ ).

The aim of this work was to evaluate the usefulness of six potential reference genes in the Atlantic salmon. Salmonid fish are among the most widely studied model fish species in general, and extensive basic information on many different aspects of their biology has been collected [19]. Large-scale DNA-sequencing projects on salmon have been initiated in several laboratories http://www.sal mongenome.no/cgi-bin/sgp.cgi; http://web.uvic.ca/cbr/ grasp/; http://www.abdn.ac.uk/sfirc/salmon/; http:// www.bcgsc.ca/gc/salmon. In this work we selected the two 'classic' reference genes encoding GAPDH and $\beta$-actin, two genes encoding $18 \mathrm{~S}$ rRNA and S20 ribosomal protein and two paralog genes encoding elongation factor $1 \mathrm{~A}$ $\left(E F 1 A_{A}\right.$ and $\left.E F 1 A_{B}\right)$. To evaluate their usefulness as reference genes, RNA from eight tissues of six adult salmon were subjected to real time PCR. The relative transcription levels of the genes were also estimated in four phases of young salmon going through smoltification, in order to check their stabilities under physiological stressful conditions.

\section{Results and discussion}

Ranking of six potential reference genes in Atlantic salmon The ranking of the six examined genes analyzed by geNorm is shown in Table 3. In six tissues (muscle, liver, gills, head kidney, spleen and thymus), the $\mathrm{EF}_{1} \mathrm{~A}_{\mathrm{B}}$ gene emerged as the most stable, whereas the $\mathrm{EF} 1 \mathrm{~A}_{\mathrm{A}}$ gene was ranked number one in brain and the $\beta$-actin gene was 
Table 3: Evaluation of the usefulness of six potential reference genes in eight tissues of Atlantic salmon ranked by the geNorm software. I = best, 6 = worst. Six individuals were analyzed for six genes in eight tissues.

\begin{tabular}{lccccccccc}
\hline Tissue & Muscle & Liver & Gills & Head kidney & Spleen & Brain & Intestine & $\begin{array}{c}\text { Thymus } \\
\text { ranking }\end{array}$ \\
\hline I8S rRNA & 3 & 5 & 6 & 2 & 3 & 5 & 6 & 4 \\
S20 & 6 & 4 & 5 & 5 & 2 & 3 & 5 & 5 & 5 \\
$\beta$-actin & 2 & 3 & 4 & 4 & 4 & 4 & 1 & 2 & 3 \\
GAPDH & 5 & 6 & 3 & 6 & 6 & 6 & 3 & 6 \\
EFIA $_{\text {A }}$ & 4 & 2 & 2 & 3 & 5 & 1 & 3 & 3 \\
EFIA $_{B}$ & 1 & 1 & 1 & 1 & 1 & 2 & 2 & 1 \\
\hline
\end{tabular}

ranked number one in intestine. The $18 \mathrm{~S}$ rRNA and S20 genes were ranked among the worse genes in all tissues. Not surprisingly, the GAPDH gene was ranked worse in five tissues (liver, head kidney, spleen, brain and thymus), confirming the general skepticism against the use of this gene as reference $[7,16,20]$. Combined, the total ranking reads $E F 1 A_{B}>E F 1 A_{A}>\beta$-actin $>18 S$ rRNA $>S 20>$ GAPDH. We did not analyze our data with the Bestkeeper software. Analyzing reference genes in virus infected cells, Radonic et al. [4] concluded that the Bestkeeper tool gave results that slightly deviated from, but nevertheless corresponded to, those obtained using geNorm.

To be able to evaluate gene stability under stressful conditions, mRNA expression of the selected genes was examined in gills of salmon going through smoltification. Prior to seawater entry, juvenile anadromous salmon undergo a parr-smolt transformation, characterized by behavioral, morphological and physiological changes, known to be challenging for the fish. Physiological alterations include increased seawater tolerance, olfactory sensitivity, metabolic rate, scope for growth and changed hemoglobin and visual pigments [21]. We selected to examine the gills during smoltification, because this tissue plays a major role in ionic and osmotic regulation during adaptation to hyperosmotic seawater. Figure 1 shows the raw $\mathrm{Ct}$ values of the studied genes in gills before, during and after smoltification (smoltified in seawater and desmoltified in freshwater). In Figure 2 the same data are presented, but now normalized against an index calculated by geNorm of the three most stable genes ( $\beta$-actin, $\mathrm{EF}_{1} \mathrm{~A}_{\mathrm{A}}$ and $\left.\mathrm{EF} 1 \mathrm{~A}_{B}\right)$. Based on the $M$ values, geNorm ranks the stability of the six genes from 24 fish going through smoltification in the following order: $E F 1 A_{B}>E F 1 A_{A}>\beta$-actin $>S 20>18 S$ rRNA $>$ GAPDH (Figure 3). In Figure 1 it can be seen that the $18 \mathrm{~S}$ gene had the lowest individual raw $\mathrm{Ct}$ variation. Most individual raw $\mathrm{Ct}$ variation of the studied genes is seen in the presmolt and smolt groups. A characteristic drop in expression can be seen for all genes in the smolt group, compared to the presmolt group. After transfer to seawater, the individual raw $\mathrm{Ct}$ variation decreased for all genes. Overall, the raw Ct data suggest that the physiological challenging smoltification process affected the expression of all six genes. When the same data were normalized against an index of the three most stable genes, $\beta$-actin, EF1 $\mathrm{A}_{\mathrm{A}}$ and $E F 1 A_{B}$, the relative expression levels were altered for all genes. Now the ribosomal $18 \mathrm{~S}$ gene emerges as the second worse, whereas the two paralog EF1A genes became the most stable. This might have to do with the fact that geNorm will top-rank co-expressed genes [22], a weakness that has to be considered when evaluating paralog genes likely to be co-regulated. Even though the eEF1A-2 gene has been identified as an important oncogene and has been shown to be differently expressed in human tissues [11], Hamalainen et al. [23] found the eEF1A-1 gene to be a good reference gene in real-time RT-PCR examinations. A similar finding was reported by Frost and Nilsen [24] in salmon louse, where they showed that the eEF1A and S20 genes were valid candidate references, whereas the $18 \mathrm{~S}$ rRNA and GAPDH genes were unsuitable. The current findings based on geNorm evaluation question the recommended application of ribosomal genes as references (as suggested for example by Ambion (see reference [15]), and are in line with earlier warnings against the use of rRNA genes as references $[5,6]$. To avoid the normalization of the genes for $\beta$-actin, EF1 $\mathrm{A}_{\mathrm{A}}$ and $\mathrm{EF} 1 \mathrm{~A}_{\mathrm{B}}$ against an index partly based on their own expression, the S20 gene was included in the index instead, and the mean normalized expression for these three genes calculated with the new index. The patterns of expression, however, were approximately the same for the three genes as seen in Figure 2, suggesting that the gene-stability measure $\mathrm{M}$ can be used to find the most appropriate reference genes.

\section{PCR poisoning}

We see a correlation between the A260/230 absorbance on the NanoDrop and the PCR efficiency (data not shown). We tend to get PCR efficiencies that are too high in some samples with low A260/230 ratios. When the samples are treated with DNase solution, the A260/230 ratio usually drops. After DNase treatment, the A260/280 ratio increased from 1.8 to 2.1 ( $\mathrm{n}=45$ samples). At the 

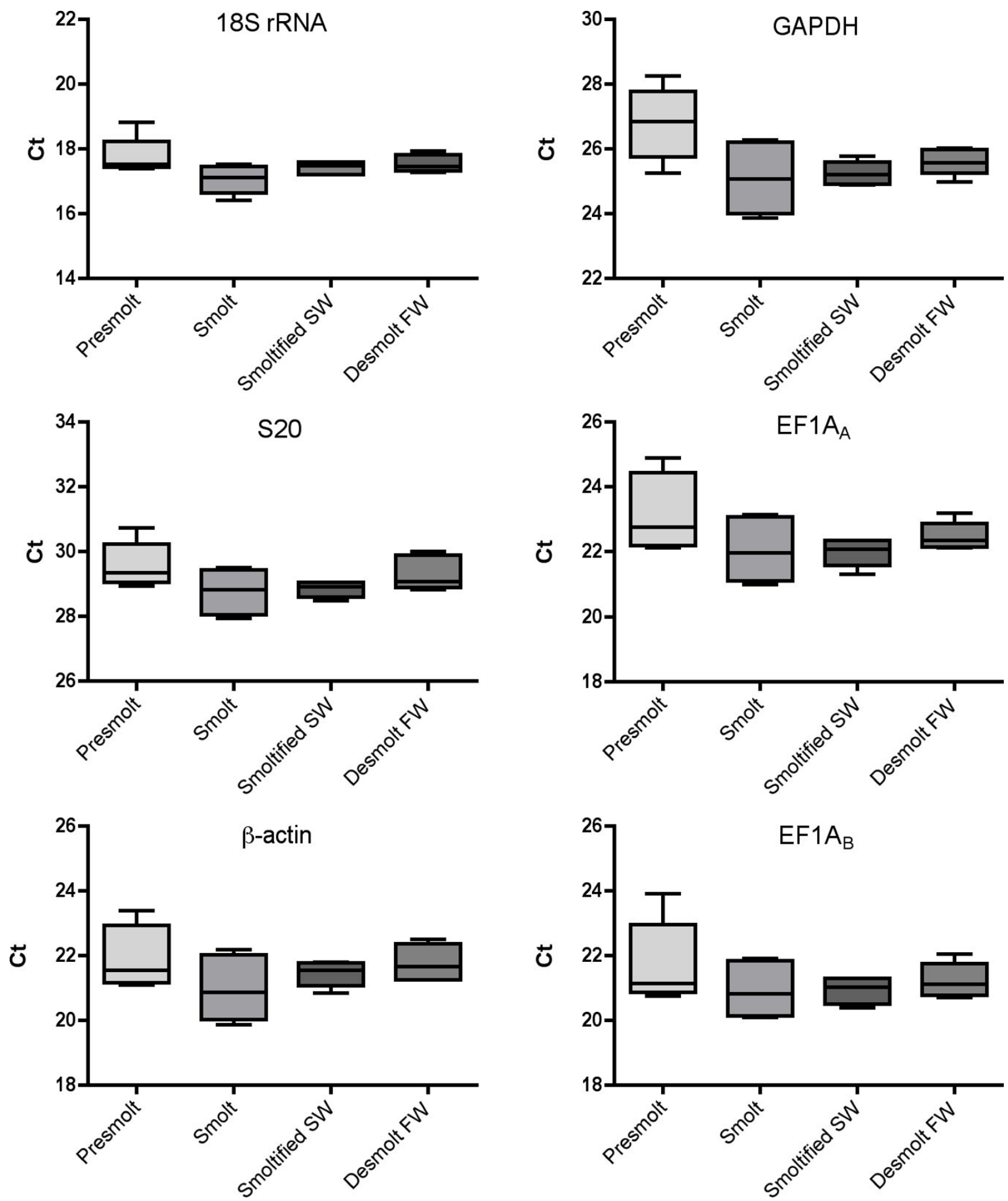

Figure I

qRT-PCR analysis of six genes in gills of six Atlantic salmon going through smoltification; presmolt (before smoltification), smolt (during smoltification), smoltified (finished smoltified in seawater) and desmolt (desmoltification in freshwater). Numbers indicate raw $\mathrm{Ct}$ values. 

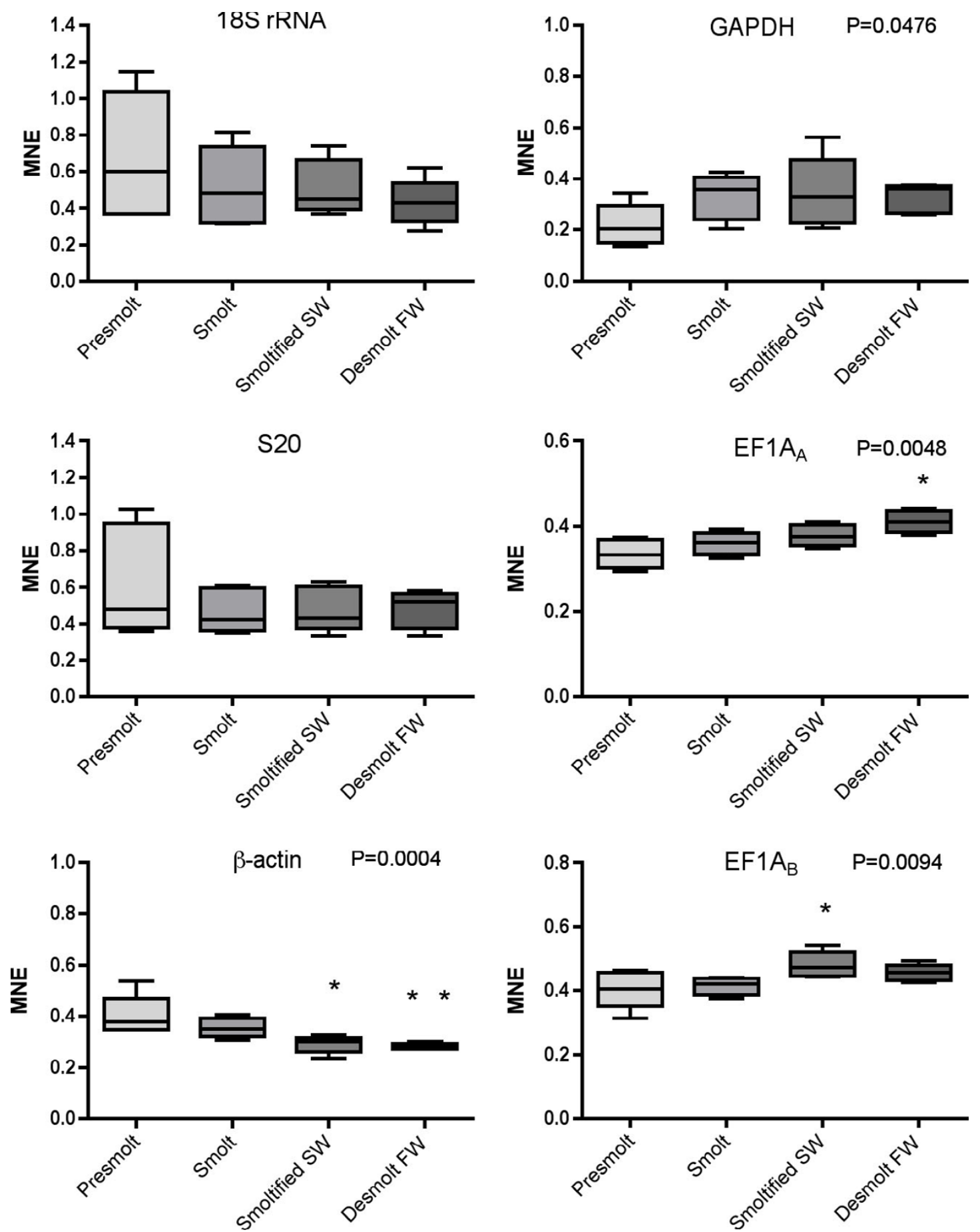

\section{Figure 2}

qRT-PCR analysis of six genes in gills of six smoltifying Atlantic salmon. The same data as in Figure I, but now normalized against an index of the three best genes ( $\beta$-actin, EFIA $A_{A}$ and $\left.E F I A_{B}\right)$ calculated with the geNorm software. The four groups were analyzed with Kruskal-Wallis test, and if significant, the overall $p$-value is given in the graphs. For $\beta$-actin, there were significant differences between the presmolt and the smoltified group $(p<0.05)$, the presmolt and the desmolt groups ( $<<0.0 \mathrm{I})$ and between the smolt and desmolt groups $(p<0.05)$. For EFIA $A_{A}$, there was a significant difference between the presmolt and the desmolt groups $(p<0.01)$. For EFI $A_{B}$, there was a significant difference between the smolt and the smoltified groups $(p<$ 0.05 ). An asterisk denotes significant differences between the groups. 


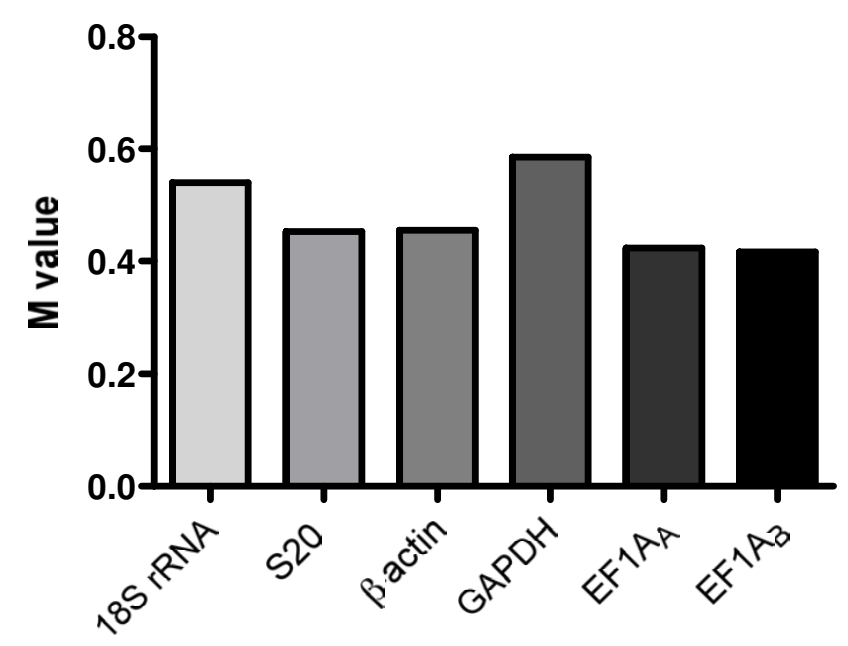

Figure 3

Stability of six genes in gills of Atlantic salmon during smoltification calculated with the geNorm software. geNorm calculates the gene expression stability measure $M$ for a control gene as the average pairwise variation $\mathrm{V}$ for that gene with all other tested control genes.

same time, the A260/230 ratio dropped from 2.4 to 2.1. The DNase treatment therefore adds substances to the RNA solution that increases the absorbance at $230 \mathrm{~nm}$ more than it decrease the $260 \mathrm{~nm}$ absorbance. The added substance (salt or some other component) may inhibit the RT reaction or the PCR reaction, sometimes called PCR poisoning. We have seen that the A260/230 ratios are quite low in samples that give inadequate PCR efficiency slopes, especially with RNA from head kidney, thymus and intestine tissues, in which the gradient of the standard curve is less than -3.3 (Table 2). The reason one obtain better amplification rate efficiencies with the more diluted samples is because the inhibitor has been diluted below its effective level. The obvious way around this problem is to dilute the amount of CDNA put into the PCR reaction. Alternatively, cleanup columns can be used to purify and concentrate the RNA.

Transcription levels of the examined genes and the coefficient of variance $(\mathrm{CV})$ in different tissues varied considerably. mRNA levels in tissues are regulated by numerous endogenous and exogenous stimuli [16]. Transcription rates in metabolic active tissues might be up-regulated compared to those of less active tissues, whereas inter-tissue variation in degradation rates of mRNAs, for example, might affect mRNA stability [25]. The results revealed that muscle had the lowest CVs of the studied genes, compared to higher CVs in more active tissues like thymus, head kidney and spleen. In thymus, intestine, head kidney, gills, brain, liver and spleen, the $18 \mathrm{~S}$ and S20 genes had the lowest CVs, based on raw Ct values. In all tissues, except intestine, the GAPDH gene had the highest CV. Except for thymus, the two elongation factor genes had relatively similar expression in all eight examined tissues. Their expression are most likely co-expressed in the examined tissues, and therefore favored in geNorm calculations [22]. The results also demonstrated that assays optimized for one tissue of an organism do not necessarily work equally well in other tissues. Of the tissues studied in this work, intestine, head kidney and spleen were the most troublesome.

\section{Conclusion}

Our data, based on geNorm calculations, suggest that the Atlantic salmon EF1A genes that have been tested in the present study may be good candidate reference genes. The GAPDH gene seems unsuitable as a reference in quantitative real-time RT-PCR. With regard to the $18 \mathrm{~S}$ rRNA gene, this must be applied with caution. Tools like the geNorm applet for Microsoft Excel can be useful to help select the most stable genes in various experiments.

\section{Methods}

\section{Fish handling and experimental design}

Tissues from 15 individuals were collected $(852 \pm 702 \mathrm{~g}$, ranging from 254 to $1898 \mathrm{~g}$ ). These individuals were not separated based on sex, size or sampling time, but treated as one heterogeneous group to examine the width of mRNA expression of the studied genes in eight different organs. This group of fish was handled and fed according to normal aquacultural management, and none of these individuals were exposed to any particular treatment. To examine if physiological stress may alter the gene expression in the gills, a total of 24 individuals were collected before (termed presmolt, $18.3 \pm 0.9 \mathrm{~g}$ ), during (termed smolt, $28.7 \pm 3.7 \mathrm{~g}$ ) and after smoltification. After smoltification, one group was kept and desmoltified in freshwater (termed desmolt FW, $30.0 \pm 3.8 \mathrm{~g}$ ), while the other group was transferred to seawater (termed smoltified SW, $30.2 \pm 4.3 \mathrm{~g})(\mathrm{n}=6$ in each group). The Atlantic salmon examined during smoltification were from the anadromous population "Vosso" of the river Vosso in Southwestern Norway (see Nilsen et al. [27] for details on how these fish were treated). All fish were treated and euthanized according to Norwegian national legislation for laboratory animals.

\section{Tissue sampling}

Samples from eight organs, i.e. gills, liver, brain, head kidney, spleen, thymus, white muscle and posterior intestine, were dissected out and immediately frozen in cryo tubes in liquid $\mathrm{N}$ and stored at $-80^{\circ} \mathrm{C}$ before RNA extraction. The RNA extracted from three spleen and four head kidney tissue samples were of low quality, and we had to redo the sampling from four individuals, These tissue samples 
Table I: TaqMan assays used to evaluate potential reference genes in Atlantic salmon.

\begin{tabular}{lcccc}
\hline Gene & Forward primer & Reverse primer & TaqMan MGB probe & Amplicon size (bp) \\
\hline I8S rRNA & CCCCGTAATTGGAATGAGTACACTTT & ACGCTATTGGAGCTGGAATTACC & CACCAGACTTGCCCTCC \\
S20 & GCAGACCTTATCCGTGGAGCTA & TGGTGATGCGCAGAGTCTTG & CCTCAAGGTGAAGGA & 98 \\
B-actin & CCAAAGCCAACAGGGAGAAG & AGGGACAACACTGCCTGGAT & TGACCCAGATCATGTTT & 91 \\
GAPDH & AAGTGAAGCAGGAGGGTGGAA & CAGCCTCACCCCATTTGATG & CTGATCATTGGAAACCT & 96 \\
EFIA A & CCCCTCCAGGACGTTTACAAA & CACACGGCCCACAGGTACA & ATCGGTGGTATTGGAAC & 57 \\
EFIA $_{B}$ & TGCCCCTCCAGGATGTCTAC & CACGGCCCACAGGTACTG & CCAATACCGCCGATTTT & 59 \\
\hline
\end{tabular}

were stored on RNA later (Ambion) at $-20^{\circ} \mathrm{C}$ before further processing.

\section{RNA extraction}

RNA was isolated with phenol-chloroform extraction as described by Chomczynski and Sacchi [28], and stored in $100 \mu \mathrm{l}$ RNase-free MilliQ $\mathrm{H}_{2} \mathrm{O}$. Total RNA was extracted using Trizol reagent (Invitrogen, Life Technologies), according to the manufacturer's instructions. Genomic DNA was eliminated from the samples by DNase treatment according to the manufacturer's description (Ambion). The RNA was then stored at $-80^{\circ} \mathrm{C}$ before further processing. The quality of the RNA was assessed with the NanoDrop ${ }^{\circledast}$ ND-1000 UV-Vis Spectrophotometer (NanoDrop Technologies, Wilmington, DE, USA) and the Agilent 2100 Bioanalyzer (Agilent Technologies, Palo Alto, CA, USA). A 260/280 nm absorbance ratio of 1.8 2.0 indicates a pure RNA sample. The RNA 6000 Nano LabChip $^{\circledast}$ kit (Agilent Technologies, Palo Alto, CA, USA) was used to evaluate the integrity of the RNA. We used the RNeasy MinElute Cleanup kit from Qiagen to purify our most troublesome samples. With this kit the A260/230 ratio increased on average by $5 \%(n=10)$.

\section{Design of PCR primers and TaqMan probes}

The PCR primer and TaqMan MGB probe sequences used for quantification of the genes encoding $18 \mathrm{~S}$ rRNA, S20 ribosomal protein, $\beta$-actin, GAPDH, EF1 $\mathrm{A}_{\mathrm{A}}$ and $\mathrm{EF} 1 \mathrm{~A}_{\mathrm{B}}$, are shown in Table 1 . Four of these genes, $18 \mathrm{~S}, \beta$-actin, EF1 $\mathrm{A}_{\mathrm{A}}$ and $\mathrm{EF} 1 \mathrm{~A}_{B}$, have also been used as references in real-time RT-PCR analyses of Atlantic salmon in other recent studies $[12,28]$. The primers amplify PCR products between 57 98 basepairs (bp) long, which is within the range of 50150 bp as suggested by Applied Biosystems for their TaqMan assays. qPCR assays were designed using Primer Express 2.0 software (Applied Biosystems, Foster City, CA, USA) to select appropriate primer and probe sequences from known Atlantic salmon genes. The mRNA sequences encoding S20 ribosomal protein and GAPDH were obtained from GenBank accession numbers BG936672 and BU693999, respectively (exon-exon borders were not considered). The EF1 $\mathrm{A}_{\mathrm{A}}$ assay was based on a cDNA clone that we reported to the GenBank previously (AF321836), whereas the EF1 $\mathrm{A}_{\mathrm{B}}$ assay was based on the EST BG933853.
An alignment with zebrafish indicated the exon-exon borders [29]. The chosen primers were subsequently used to confirm that the salmon genes contained an intron between the same sites as deduced from the alignment with zebrafish. The PCR products containing the introns were cloned into TOPO vector (Invitrogen) and sequenced (sequences can be provided upon request). PCR primers for $\beta$-actin were based on Atlantic salmon BG933897 and designed to span exon-exon borders of this gene, as deduced from corresponding genes in human and zebrafish (NW633959). For 18 S rRNA the PCR primers and probe were designed from the Atlantic salmon sequence $\mathrm{AJ} 427629$, and placed in a conserved region of the gene based on comparison with the human gene. RNA samples were subjected to DNase treatment to avoid genomic DNA contamination. Amplified PCR products of all actual cDNAs were sequenced to ensure that the correct mRNA sequences were quantified. The fragments were sequenced with BigDye version 3.1 fluorescent chemistry (Applied Biosystems) and run on an ABI PRISM ${ }^{\circledR} 377$ DNA apparatus at the University of Bergen Sequencing Facility.

\section{Real-time quantitative $R T-P C R$}

A two-step real-time RT-PCR protocol was developed to measure the mRNA levels of the studied genes in eight tissues of Atlantic salmon. The RT reactions were run in triplicate on 96-well reaction plates with the GeneAmp PCR 9700 machine (Applied Biosystems, Foster City, CA, USA) using TaqMan Reverse Transcription Reagent containing Multiscribe Reverse Transcriptase (50 U/ $\mu \mathrm{l})$. Two-fold serial dilutions of total RNA were made for efficiency calculations. Five or six serial dilutions (500 - 15,63 ng) were analyzed by qRT-PCR in separate sample wells and the resulting Cts recorded. Input total RNA concentration was $500 \mathrm{ng}$ in each reaction for $\beta$-actin, GAPDH, EF1A and $\mathrm{EF} 1 \mathrm{~A}_{\mathrm{B}}$, and $0.5 \mathrm{ng}$ for $18 \mathrm{~S}$ rRNA and S20 ribosomal protein. Controls for no template (ntc) and controls for no amplification (nac) were run for each master mix, but not for every single sample. Reverse transcription was performed at $48^{\circ} \mathrm{C}$ for $60 \mathrm{~min}$ by using oligo dT primers $(2.5$ $\mu \mathrm{M})$ for $\beta$-actin, GAPDH, EF1A $\mathrm{A}_{\mathrm{A}}$ and $\mathrm{EF}_{\mathrm{A}} \mathrm{A}_{\mathrm{B}}$ and random hexamer primers $(2.5 \mu \mathrm{M})$ for $18 \mathrm{~S}$ and $\mathrm{S} 20$ in $30 \mu \mathrm{l}$ total volume. cDNA for evaluation of smoltification effects ( 24 
Table 2: Standard curve evaluation of potential reference genes in Atlantic salmon.

\begin{tabular}{|c|c|c|c|c|c|c|c|c|}
\hline & \multicolumn{2}{|c|}{ Thymus } & \multicolumn{2}{|c|}{ Muscle } & \multicolumn{2}{|c|}{ Intestine } & \multicolumn{2}{|c|}{ Head kidney } \\
\hline & Slope & $\mathrm{R}^{2}$ & Slope & $\mathrm{R}^{2}$ & Slope & $\mathrm{R}^{2}$ & Slope & $\mathrm{R}^{2}$ \\
\hline I8S rRNA & -3.26 & 0.996 & -3.40 & 0.993 & -3.23 & 0.992 & -3.27 & 0.998 \\
\hline $\mathrm{S} 20$ & -3.28 & 0.996 & -3.21 & 0.991 & -3.29 & 0.990 & -3.07 & 0.993 \\
\hline$\beta$-actin & -2.73 & 0.994 & -3.36 & 0.997 & -3.11 & 0.997 & -3.05 & 0.996 \\
\hline GAPDH & -3.38 & 0.997 & -3.21 & 0.995 & -3.37 & 0.996 & -3.13 & 0.996 \\
\hline$E F \mid A_{A}$ & -3.06 & 0.996 & -3.05 & 0.993 & -3.05 & 0.994 & -3.06 & 0.996 \\
\hline \multirow[t]{3}{*}{$E F I A_{B}$} & -3.11 & 0.998 & -3.13 & 0.998 & -3.20 & 0.993 & -3.31 & 0.997 \\
\hline & \multicolumn{2}{|c|}{ Gills } & \multicolumn{2}{|c|}{ Brain } & \multicolumn{2}{|c|}{ Liver } & \multicolumn{2}{|c|}{ Spleen } \\
\hline & Slope & $\mathrm{R}^{2}$ & Slope & $\mathrm{R}^{2}$ & Slope & $\mathrm{R}^{2}$ & Slope & $\mathrm{R}^{2}$ \\
\hline I8S rRNA & $-3.4 I$ & 0.999 & -3.32 & 0.992 & -3.42 & 0.998 & -3.20 & 0.995 \\
\hline S20 & -3.29 & 0.990 & -3.22 & 0.991 & -3.39 & 0.991 & -3.28 & 0.995 \\
\hline$\beta$-actin & -3.10 & 0.999 & -3.21 & 0.997 & -3.23 & 0.990 & -3.44 & 0.994 \\
\hline GAPDH & -3.57 & 0.997 & -3.48 & 0.902 & -3.21 & 0.995 & -2.83 & $0.7 \mid 4$ \\
\hline$E F \mid A_{A}$ & -3.38 & 0.998 & -2.86 & 0.994 & -3.11 & 0.994 & -3.15 & 0.992 \\
\hline$E F \mid A_{B}$ & -3.32 & 0.991 & -3.14 & 0.991 & -3.24 & 0.991 & -3.52 & 0.996 \\
\hline
\end{tabular}

samples) were primed entirely with random nonamer primers. In this material, total RNA were treated with RQ1 RNase-free DNase (Promega) and cDNA reversely transcribed using $500 \mathrm{ng}$ total RNA and random nonamers in conjunction with the Reverse Transcription Core kit (EuroGenTech, RT-RTCK-05) following the manufacturer's instructions. Input total RNA concentration was $500 \mathrm{ng}$ in each reaction. All 24 samples for each gene were run on the same plate together with six serial dilutions. The final concentration of the other chemicals in each RT reaction was: $\mathrm{MgCl}_{2}(5.5 \mu \mathrm{M})$, dNTP (500 $\mu \mathrm{M}$ of each), $10 \times$ TaqMan RT buffer $(1 \times)$, RNase inhibitor $(0.4 \mathrm{U} / \mu \mathrm{l})$ and Multiscribe Reverse Transcriptase (1.67 U/ $\mu \mathrm{l})$.

$2.5 \mu \mathrm{l}$ of 10 -fold diluted cDNA for $\beta$-actin, GAPDH, EF1A and $\mathrm{EF} 1 \mathrm{~A}_{\mathrm{B}}$, and 1000-fold diluted CDNA for 18S rRNA and S20 ribosomal protein from each RT reaction was transferred to a new 96-well reaction plate, and the realtime PCR run on the ABI Prism 7000 Sequence Detection System from AB. Real-time PCR was performed by using TaqMan Universal PCR Master Mix, which contains AmpliTaq Gold ${ }^{\circledR}$ DNA polymerase, and gene specific primers (900 nM). Fluorescence marked TaqMan MGB probes (200 nM) were used for data collection during the log linear phase of the reaction. PCR was achieved with a $10 \mathrm{~min}$ activation and denaturation step at $95^{\circ} \mathrm{C}$, followed by 50 cycles of $15 \mathrm{~s}$ at $95^{\circ} \mathrm{C}$ and $60 \mathrm{~s}$ at $60^{\circ} \mathrm{C}$. Baseline and threshold for $\mathrm{Ct}$ calculation were set automatically with the ABI Prism 7000 SDS software version 1.1, or set manually whenever necessary.
For evaluation of the potential reference genes, raw Ct values are presented. The geNorm VBA applet for Microsoft Excel was used to determine the most stable genes from the set of tested genes [5]. The Ct values were transformed to quantities using standard curves, according to the geNorm manual. The gene expression stability (M) was calculated with the geNorm applet, and the genes were ranked from best to worst, based on the $M$ value.

\section{Statistics}

The GraphPad Prism 4.0 software (GraphPad Software, Inc.) was used for the statistical analyses in this work. Linear regression was used to determine PCR efficiency based on dilution curves. Non-parametric Kruskal-Wallis test was used to compare differences among four groups of salmon going through smoltification.

\section{Authors' contributions}

PAO was responsible for the experiment, data analysis and drafted the manuscript. KKL conducted the real-time RT-PCR analysis, and contributed throughout the experimental process. AEOJ constructed the qPCR assays for two of the genes. TON provided the cDNA from the smoltification experiment. IH participated as a supervisor in the study design, analyses and writing.

\section{Acknowledgements}

We gratefully acknowledge Chris Glover for checking the language. This work was financed by the National Institute of Nutrition and Seafood Research, Bergen, Norway. IH was funded by a grant for functional genomics (FUGE) from the Norwegian Research Council. 


\section{References}

I. Bustin SA, Nolan T: Analysis of mRNA expression by real-time PCR In Real-time PCR. An essential guide Edited by: Edwards K, Logan J, Saunders N. Norfolk, UK: Horizon Bioscience; 2004: I25-184.

2. Dheda K, Huggett JF, Bustin SA, Johnson MA, Rook G, Zumla A: Validation of housekeeping genes for normalizing RNA expression in real-time PCR. Biotechniques 2004, 37(I): I I 2-I I 9.

3. Radonic A, Thulke S, Mackay IM, Landt O, Siegert W, Nitsche A Guideline to reference gene selection for quantitative realtime PCR. Biochem Biophys Res Comm 2004, 3 I 3(4):856-862.

4. Radonic A, Thulke S, Bae HG, Muller MA, Siegert W, Nitsche A: Reference gene selection for quantitative real-time PCR analysis in virus infected cells: SARS corona virus, Yellow fever virus, Human Herpesvirus-6, Camelpox virus and Cytomegalovirus infections. Virol J 2005, 2(7):

5. Vandesompele J, Preter KD, Pattyn F, Poppe B, Roy NV, Paepe AD, Speleman F: Accurate normalization of real-time quantitative RT-PCR data by geometric averaging of multiple internal control genes. Genome Biol 2002, 3(7):research0034. I-0034. I I.

6. Pfaffl MW, Tichopad A, Prgomet C, Neuvians TP: Determination of stable housekeeping genes, differently regulated target genes and sample integrity: BestKeeper - Excel-based tool using pair-wise correlations. Biotechnol Letters 2004, 26:509-5 I 5.

7. Huggett J, Dheda K, Bustin S, Zumla A: Real-time RT-PCR normalisation; strategies and considerations. Genes Immun 2005 , 6(4):279-284.

8. Suzuki T, Higgins P, Crawford DR: Control selection for RNA quantitation. Biotechniques 2000, 29(2):332-337.

9. Rubie C, Kempf K, Hans J, Su T, Tilton B, Georg T, Brittner B, Ludwig $B$, Schilling $M$ : Housekeeping gene variability in normal and cancerous colorectal, pancreatic, esophageal, gastric and hepatic tissues. Mol Cell Probes 2005, I 9(2): I01-9.

10. Sirover MA: New insights into an old protein: the functional diversity of mammalian glyceraldehyde-3-phosphate dehydrogenase. Biochim Biophys Acta-Protein Struct Mol Enzymol 1999, 1432(2): I59-184.

II. Thornton S, Anand N, Purcell D, Lee J: Not just for housekeeping: protein initiation and elongation factors in cell growth and tumorigenesis. J Mol Med 2003, 8 I(9):536-548.

12. Moore LJ, Somamoto T, Lie KK, Dijkstra JM, Hordvik I: Characterisation of salmon and trout CD8a and CD8b. Mol Immunol 2005, 42: 1225-1234.

13. Allendorf FW, Thorgaard GH: Tetraploidy and the evolution of salmonid fishes. In Evolutionary Genetics of Fishes Edited by: Turner BJ. New York: Plenum Press; 1984: I-55.

14. Hordvik I: The impact of ancestral tetraploidy on antibody heterogeneity in salmonid fishes. Immunol Rev 1998 , I66:153-I57.

15. RT-PCR: The basic. [http://www.ambion.com/techlib/basics/rtpcr/ index.html].

16. Bustin SA, Nolan T: Data analysis and interpretation. In $A-Z$ of quantitative PCR Edited by: Bustin SA. La Jolla, Ca, USA: International University Line; 2004:44 I-492.

17. Biederman J, Yee J, Cortes P: Validation of internal control genes for gene expression analysis in diabetic glomerulosclerosis. Kidney Int 2004, 66(6):2308-23 I4.

18. Hoerndli FJ, Toigo M, Schild A, Gotz J, Day PJ: Reference genes identified in SH-SY5Y cells using custom-made gene arrays with validation by quantitative polymerase chain reaction. Anal Biochem 2004, 335(I):30-4I.

19. Thorgaard GH, Bailey GS, Williams D, Buhler DR, Kaattari SL, Ristow SS, Hansen JD, Winton JR, Bartholomew JL, Nagler JJ, Walsh PJ Vijayan MM, Devlin RH, Hardy RW, Overturf KE, Young WP, Robison $B D$, Rexroad C, Palti Y: Status and opportunities for genomics research with rainbow trout. Comp Biochem Physiol B-Biochem $\mathrm{Mol}$ Biol 2002, I33(4):609-646.

20. Zhang X, Ding L, Sandford AJ: Selection of reference genes for gene expression studies in human neutrophils by real-time PCR. BMC Mol Biol 2005, 6(I):4.

21. McCormick SD, Hansen LP, Quinn TP, Saunders RL: Movement, migration, and smolting of Atlantic salmon (Salmo salar). Can J Fish Aquat Sci 1998, 55(Suppl I):77-92.

22. Bustin SA, Benes V, Nolan T, Pfaffl MW: Quantitative real-time RT-PCR - a perspective. J Mol Endocrin 2005, 34:597-60I.

23. Hamalainen HK, Tubman JC, Vikman S, Kyrola T, Ylikoski E, Warrington JA, Lahesmaa R: Identification and validation of endog- enous reference genes for expression profiling of $T$ helper cell differentiation by quantitative real-time RT-PCR. Anal Biochem 200I, 299:63-70.

24. Frost $\mathrm{P}$, Nilsen F: Validation of reference genes for transcription profiling in the salmon louse, Lepeophtheirus salmonis, by quantitative real-time PCR. Vet Parasitol 2003, I I 8: | 69-I74.

25. Meyer S, Temme C, Wahle E: Messenger RNA turnover in eukaryotes: pathways and enzymes. Crit Rev Biochem Mol Biol 2004, 39(4): 197-216.

26. Nilsen TO, Ebbesson LOE, Stefanson SO: Smolting in anadromous and landlocked strains of Atlantic salmon (Salmo salar). Aquaculture 2003, 222:71-82.

27. Chomczynski P, Sacchi N: Single-step method of RNA isolation by acid guanidinium thiocyanate-phenol-chloroform extraction. Anal Biochem 1987, 162:156-159.

28. Olsvik PA, Kristensen T, Waagbø R, Rosseland BO, Tollefsen K-E, Baeverfjord G, Berntssen MHG: mRNA expression of antioxidant enzymes (SOD, CAT and GSH-Px) and lipid peroxidative stress in liver of Atlantic salmon Salmo salar exposed to water hyperoxic conditions during smoltification. Comp Biochem Physiol C-Toxicol Pharmacol 2005, |4 I:3|4-323.

29. Gao D, Li Z, Murphy T, Sauerbier W: Structure and transcription of the gene for translation elongation factor I subunit alpha of zebrafish (Danio rerio). Biochim Biophys Acta 1996, I350: |-5.
Publish with BioMed Central and every scientist can read your work free of charge

"BioMed Central will be the most significant development for disseminating the results of biomedical research in our lifetime. "

Sir Paul Nurse, Cancer Research UK

Your research papers will be:

- available free of charge to the entire biomedical community

- peer reviewed and published immediately upon acceptance

- cited in PubMed and archived on PubMed Central

- yours - you keep the copyright
BioMedcentral 